\title{
Productive performance of Holstein calves finished in feedlot or pasture
}

\author{
ANA MARIA O. DIAS, LUIS F.G. DE MENEZES, WAGNER PARIS, PRISCILA V. DOS SANTOS, \\ RONALDO R. BIESEK, RENAN D. MAFIOLETTI and RENATO MARCHESAN
}

Universidade Tecnológica Federal do Paraná, Campus Dois Vizinhos, Estrada para Boa Esperança, Km 04, 85660-000 Dois Vizinhos, PR, Brazil

Manuscript received on February 14, 2017; accepted for publication on May 14, 2017

\begin{abstract}
The use of animals from dairy farms is an alternative to meat production since it provides an increment of total income for farmers. This study aims to evaluate the performance of Holstein calves finished in two feeding systems (feedlot or pasture). Forty-three animals with 58 days old and $57 \mathrm{~kg}$ were divided in two treatments: 23 animals finished in feedlot with corn silage plus concentrate based on corn and soybean meal (40:60); 20 animals kept in cultivated pastures according to the period of the year: Italian ryegrass (Lolium multiflorum) and pearl millet (Pennisetum americanum) with supplementation with the same feedlot-concentrate at $1 \%$ body weight. Animals were slaughtered with $200 \mathrm{~kg}$. Dry matter and nutrient intake were determined, with the use of chromium oxide for estimating pasture intake. Feedlot animals had greater total intake and total digestible nutrients, resulting in higher average daily gain (0.949 vs $0.694 \mathrm{~kg} \mathrm{day}^{-1}$ ). Crude protein intake, neutral detergent fiber and feed conversion did not show significant differences. Holstein calves have improved performance when finished in feedlot.
\end{abstract}

Key words: cattle, forage intake, chromium oxide, feeding systems.

\section{INTRODUCTION}

The great interest of research on meat production has been growing considerably, aiming at improving quality of products and alternatives that contribute to meet the increasing demand for animal protein of the consumer market. For this reason, the use of animals from dairy farms with no immediate use becomes an alternative for meat marketing. In addition, it provides an increment in income for small farmers, avoiding financial losses and the slaughter of dairy male calves at birth.

Correspondence to: Wagner Paris

E-mail: wagparis@yahoo.com.br
In several countries, Holstein herds are used for calf production to meet the needs of the market. The production of these animals was mainly developed in Europe due to the demand for specialty meats, representing $20 \%$ of all meat consumed on the continent. It comprises a growing market for consumers in a search for a final product with a light color and less harmful to health due to the lower fat content (Mousquer et al. 2013).

However, calf meat itself is a good alternative for consumption because it meets the demand for healthy products in addition to decrease production costs for farmers by around 70\% (Roma Junior et al. 2008). In this sense, the reduction of slaughter age 
optimizes area usage and it increases the number of cows, which results in increased meat production, optimizing performance and time (Missio et al. 2009).

The use of dairy breeds for meat production is still unknown to the productive chain. Performance and feed intake evaluation of these animals subjected to different production systems contributes to the demystification of productive inefficiency of dairy animals for meat production. Rearing these animals in high quality pastures and optimizing its performance with the use of concentrates can be a viable alternative.

Another alternative for finishing cattle is the feedlot, which shortens feeding period, resulting in high earnings and performance; however, the greater amount of manpower required and use of conserved forage and concentrates have high cost. The aim of the present study was to evaluate the productive performance of Holstein calves finished in two feeding system (pasture or feedlot) slaughtered with an average live weight of $200 \mathrm{~kg}$.

\section{MATERIALS AND METHODS}

The trial was performed from September 2011 to March 2012, lasting about 215 days, at the Teaching and Research Unit of Beef Cattle of the Experimental Farm from the Universidade Tecnológica Federal do Paraná (UTFPR) on Dois Vizinhos campus, located at $25^{\circ} 42^{\prime} 52^{\prime}$ " latitude $\mathrm{S}$ and longitude $53^{\circ} 03^{\prime} 94^{\prime \prime} \mathrm{W}$, at 519 altitude. The climate is a subtropical humid mesothermic ( $\mathrm{Cfa})$ according to Köppen classification. Climate data during the trial period are presented on Table I.

Forty-three entire Hostein animals were used, of an average age of 58 days and average initial weight of $57 \mathrm{~kg}$; 20 animals were kept in pasture and 23 were finished in feedlot, distributed in a completely randomized experimental design. Slaughter occurred with an average weight of 200 $\mathrm{kg}$. Feedlot animals remained in individual stalls (4 $\mathrm{m}^{2}$ ) and the other animals remained in cultivated pastures with different sward height, according to the herbage allowance of $10 \%$ to ryegrass (Lolium multiflorum) and pearl millet (Pennisetum americanum).

Feedlot animals were fed corn silage as roughage source and concentrate based on corn and soybean meal at 40:60 ratio. The diet was formulated based on the nutritional requirements established by the NRC (2001), for an expected average daily weight gain of $1.0 \mathrm{~kg} \mathrm{day}^{-1}$.

During the experimental period, feed was provided twice a day at 8:30 a.m. and 4:00 p.m. Before feed supply, feed leftovers were collected from individual troughs. The leftovers were kept at around $10 \%$ of the total supply and, when necessary, the quantity of feed provided was adjusted.

For the determination of feed intake, the amount of feed provided and leftovers were recorded daily. Samples of the leftovers from each trough were collected daily. These samples were grouped in composite samples according to each period for further chemical analysis.

The continuous stocking system was used for animals kept in pasture, with forage allowance of $10 \%$ of live weight (LW) through the put-and-take technique. The differentiation between ryegrass and millet pastures was necessary due to their life cycle speed and weight gain of animals until slaughter weight. For determining forage availability, the double sampling was performed every 28 days.

The estimation of the pasture intake was conducted in three evaluations. Firstly, the animals were kept in ryegrass (Lolium multiflorum) pastures with $418 \mathrm{~kg} \mathrm{ha}^{-1}$ of leaf blade from September to November 2011.In the two subsequent periods, millet (Pennisetum americanum) pasture provided a total of 2,307 $\mathrm{kg} \mathrm{ha}^{-1}$ of leaf blade from December 2011 to February 2012. The animals also received the same concentrate supplementation used in feedlot at $1 \%$ of body weight, in addition to free access to water and mineral salt. 
For evaluation of pasture intake, chromium oxide was used as external marker. Eight animals were used to estimate intake, with an average age of 80,140 and 180 days for the three evaluation periods. Chromium oxide was provided daily during 10 days at 10 grams per animal, administered by mouth once daily.

Chromium oxide was packaged in paper cartridge and administered by a hose with plunger at the time of supplementation (12 a.m.). Fecal samples were collected in the last five days, after the sixth day of chromium oxide supply. Collections were divided into three separate times during the day (8 a.m., 1 p.m. and 5 p.m.). Samplings were made directly from the rectum of each animal, removing approximately 100 to $200 \mathrm{~g}$ of feces per sampling.

After collected, the samples were immediately frozen and dried in a forced ventilation oven at $65^{\circ}$ $\mathrm{C}$ until constant weight for the determination of dry matter. Subsequently, they were Wiley milled through a $1 \mathrm{~mm}$ mesh. A sample per animal in each period was used for determination, in the laboratory, of the chromium content and nutrients in feces. For determination of chromium in fecal samples, the technique of atomic absorption spectrophotometry described by Williams et al. (1962) was used.

Fecal excretion was estimated using the following equation: Fecal Excretion $=$ Chromium oxide administered $\left(\mathrm{g}_{\text {day }}{ }^{-1}\right)$ - chromium oxide concentration in feces $\left(\mathrm{g} \mathrm{g} \mathrm{DM}^{-1}\right)$.

Chrome recovery rates $(\mathrm{CRr})$ provided to the animals were calculated through the total chrome excreted:

$\mathrm{CRr}=$ fecal chrome $\left(\mathrm{g} \mathrm{kg}^{-1}\right) * \mathrm{~kg}$ feces/Chrome administered (g)

Dry matter intake was calculated indirectly, i.e., by subtracting the fecal productions calculated from forage and concentrate digestibility and total fecal excretion obtained in the model.

DMI = Fecal Production / (1-IVDMD).
In which: DMI = Dry matter Intake, kg; Fecal production in $\mathrm{g}$ DM an ${ }^{-1} \mathrm{day}^{-1}$; and IVDMD $=$ In vitro dry matter digestibility.

The calculation of the crude protein intake (CPI), neutral (INDF) and acid (IADF) detergent fiber intake and total digestible nutrients intake (TDNI) was conducted using the values of dry matter intake and nutrient content of the diet.

The animals were weighted every 28 days after fasting of solids and liquids for approximately 14 hours to obtain the average daily gain (ADG). Feeding conversion was calculated by dividing the estimated dry matter intake by the average daily gain during the trial period.

The technique of simulated grazing for the determination of chemical composition of forage ingested was used. The samples were weighed and taken to the drying oven at $65^{\circ} \mathrm{C}$ until constant weight for determination of dry matter. Subsequently, they were Wiley milled through a $2 \mathrm{~mm}$ mesh for performing chemical analysis.

The samples obtained from the evaluation of forage availability were used for the botanic separation of the plant in its constituents: leaf, stem and senescent material, which were dried and weighted to determine the availability of each constituent.

Crude protein (CP) levels were evaluated by the Kjeldahl (AOAC, 2012) method. Neutral detergent fiber (NDF) and acid detergent fiber (ADF) were determined by the Van Soest et al. (1991) method. In vitro dry matter digestibility was performed according to Tilley and Terry (1963) method, which was used for determination of fecal production and estimation of dietary TDN. The TDN estimation was calculated from digestible organic matter (DOM), using the following equation described by Kunkle and Bates (1998):

$\mathrm{TDN}=\mathrm{OM}\{[26.8+0,595$ (IVOMD)] 100$\}$;

In which: TDN $=$ total digestible nutrients $(\%)$, IVDOM $=$ in vitro organic matter digestibility $(\%)$ and $\mathrm{OM}=$ organic matter $(\%)$. 
TABLE I

Minimum, maximum and average temperatures, relative humidity and precipitation during the period from September 2011 to February 2012.

\begin{tabular}{|c|c|c|c|c|c|}
\hline \multirow[t]{2}{*}{ Month } & \multicolumn{3}{|c|}{ Temperature $\left({ }^{\circ} \mathrm{C}\right)$} & \multirow[t]{2}{*}{ Air relative humidity (\%) } & \multirow[t]{2}{*}{ Precipitation (mm) } \\
\hline & Minimum & Maximum & Average & & \\
\hline September & 10.0 & 34.9 & 19.06 & 65.36 & 75.8 \\
\hline October & 10.6 & 33.0 & 21.25 & 67.75 & 234.0 \\
\hline November & 12.1 & 33.0 & 21.63 & 67.63 & 139.0 \\
\hline December & 11.0 & 35.7 & 23.4 & 63.9 & 42.6 \\
\hline January & 15.1 & 33.1 & 23.04 & 68.85 & 177.4 \\
\hline February & 15.1 & 36.8 & 19.2 & 70.20 & 162.0 \\
\hline
\end{tabular}

Source: UTFPR Meteorological station, 2012.

TABLE II

Chemical composition of ingredients of the experimental diets.

\begin{tabular}{cccccccc}
\hline \multirow{2}{*}{ Ingredients } & \multicolumn{7}{c}{ Components } \\
\cline { 2 - 8 } & DM \% & CP \% & NDF \% & ADF \% & MM \% & TDN \% & ivDDM \% \\
\hline Concentrate & 84.00 & 19.00 & 18.02 & 9.27 & 6.9 & 69.88 & 79.24 \\
Silage & 28.73 & 8.38 & 45.14 & 30.16 & 1.58 & 60.51 & 57.13 \\
Ryegrass & 38.82 & 26.50 & 42.46 & 18.40 & 7.16 & 55.8 & 54.95 \\
Pearl Millet & 21.25 & 22.36 & 58.46 & 29.85 & 7.40 & 56.16 & 55.29 \\
\hline
\end{tabular}

DM: dry matter; CP: crude protein; NDF: neutral detergent fiber; ADF: acid detergent fiber; MM: mineral mater; TDN: total digestible nutrients; ivDDM: in vitro digestibility dry matter.

The mathematical model used in this study is described below and the initial weight of the animals was used as co-variable: $\mathrm{Y}_{\mathrm{ij}}=\mu+\mathrm{PI}_{\mathrm{i}}+\mathrm{ST}_{\mathrm{j}}$ $+\mathrm{E}_{\mathrm{ij}}$

In which, $\mathrm{Y}_{\mathrm{ij}}=$ dependent variables; $\mu=$ general average; $\mathrm{PI}_{\mathrm{I}}=$ effect of the $\mathrm{i}^{- \text {th }}$ initial weight; $\mathrm{ST}_{\mathrm{J}}$ $=$ effect of the $\mathrm{j}^{\text {th }}$ feeding system (pasture and feedlot); $\mathrm{E}_{\mathrm{ij}}=$ residual random error.

The results were submitted to analysis of variance at 5\% significance level using the SAS (2002) statistical program.

All procedures were carried out according to the International Practices for Animal Use and Care under the control of an internal Committee of the Universidade Tecnológica Federal do Paraná, Brazil.

\section{RESULTS AND DISCUSSION}

The highest $\mathrm{DM}$ intake $(\mathrm{P}<0.05)$ was verified in feedlot animals (Table III) due to the higher intake of concentrate $(2.61 \% \mathrm{LW})$. High DM intake is directly associated with the ability of an animal to achieve its potential for growth. Therefore, animals with greater potential for growth as the Holstein breed (and greater nutritional requirement) have higher feed intake (Fernandes et al. 2004).

The high intake in feedlot animals $(4.36 \%$ LW) is a result of the higher rate of passage of concentrate $(60 \%$ of the diet) and average live weight of animals (130 kg). Growing animals, with a live weight under $150 \mathrm{~kg}$, have greater intake in relation to the percentage of live weight 
TABLE III

Dry mater intake (DMI), Total digestible nutrients intake (TDNI) crude protein intake (CPI), neutral detergent fiber intake (NDFI), acid detergent fiber intake (ADFI) in $\mathrm{kg}$ and percentage of live weight $(\% \mathrm{LW})$ of Holstein calves terminated in feedlot or pasture.

\begin{tabular}{|c|c|c|c|c|}
\hline \multirow{2}{*}{ Variables } & \multicolumn{2}{|c|}{ Feeding System } & \multirow{2}{*}{$\mathbf{P}>\mathbf{F}$} & \multirow{2}{*}{$\mathrm{VC} \%$} \\
\hline & Feedlot & Pasture & & \\
\hline DMI (kg) & $5.65 \pm 0.19$ & $4.33 \pm 0.2$ & 0.0001 & 31.83 \\
\hline DMI (\% LW) & $4.36 \pm 0.25$ & $3.32 \pm 0.25$ & 0.0077 & 31.83 \\
\hline TDNI (kg) & $3.70 \pm 0.21$ & $2.58 \pm 0.21$ & 0.0007 & 32.15 \\
\hline TDNI (\% LW) & $2.88 \pm 0.16$ & $2.01 \pm 0.41$ & 0.0007 & 32.15 \\
\hline CPI (kg) & $0.82 \pm 0.05$ & $0.93 \pm 0.05$ & 0.1850 & 30.66 \\
\hline $\mathrm{CPI}(\% \mathrm{LW})$ & $0.64 \pm 0.04$ & $0.72 \pm 0.04$ & 0.1850 & 30.66 \\
\hline NDFI (kg) & $1.61 \pm 0.10$ & $1.74 \pm 0.10$ & 0.3628 & 32.03 \\
\hline NDFI (\% LW) & $1.25 \pm 0.08$ & $1.34 \pm 0.08$ & 0.3628 & 32.03 \\
\hline ADFI (kg) & $0.98 \pm 0.05$ & $0.85 \pm 0.05$ & 0.0002 & 31.85 \\
\hline ADFI (\% LW) & $0.76 \pm 0.04$ & $0.65 \pm 0.04$ & 0.0002 & 31.85 \\
\hline
\end{tabular}

P - Probability; VC - variation coefficient.

according to NRC (2001) estimates. Holstein male animals with $150 \mathrm{~kg} \mathrm{LW}$ fed diets above $60 \%$ TDN consume approximately $4 \%$ of live weight. Aharoni et al. (2004) found that increased intake was accompanied by reduced retention time of digesta and herbage biomass had only minor effect, whereas herbage composition and digestibility had major effects on intake. The discrepancy of results between studies that assess different diets based on the supply of concentrate for feedlot or grazing animals allows to infer that the dry matter intake is a complex variable. Hence, it can be altered by many factors, such as the animal, feed form, rate of passage and climatic conditions, which interact with each other (Costa et al. 2005).

Regardless of feeding strategy used, the different forage quality affect DM intake, which is entirely influenced by fiber digestibility (Figueiras et al. 2010). In the present study, the amount of NDF ingested was similar but the digestibility of concentrate (79.24\%) allowed higher dry matter intake in feedlot animals. Fiems et al. (2012), observing the feeding system of calves for veal production, reported that the DM intake for those fed corn silage was low $\left(0.361 \mathrm{~kg} \mathrm{day}^{-1}\right)$, while feedlot animals fed high-concentrate diet show an intake of $0.857 \mathrm{~kg} \mathrm{day}^{-1}$ as a result of greater digestibility of concentrate, allowing high dietary intake by feedlot animals.

Total digestible nutrient intake (TDNI) was higher $(\mathrm{P}<0.05)$ in feedlot animals. As for dry matter intake, this difference is linked to the higher proportion of concentrate supplied in the diet, which is related to energy levels coupled with dry matter intake. In addition, TDN content was higher in the diet of feedlot animals $(66.12 \%$ versus $60.14 \%$ ) mainly to the higher energy content of the forage used. Corn silage had $60.51 \%$ TND, while pastures had an average of $55.98 \%$. The results of this study are similar to those found by Cardoso et al. (2000). NRC (2001) established that, in dairy calves, energy intake ranges from 1.37 the $2.72 \mathrm{~kg}$ 
TDN for animals from 40 to $150 \mathrm{~kg}$. In this study, feedlot animals had higher TDN intake $(3.7 \mathrm{~kg})$. In pastures, the energy supply remained within the indicated values $(2.58 \mathrm{~kg})$; therefore, it met the nutritional requirements of the calves.

Crude protein intake was similar $(\mathrm{P}>0.05)$. According to NRC (2001), the amount required for growing calves, from 60 to $150 \mathrm{~kg}$, is from 0.114 to $0.459 \mathrm{~kg} \mathrm{CP} \mathrm{day}{ }^{-1}$. This high amount of protein consumed is associated with the high dry matter intake $(4.36 \%)$.

Neutral detergent fiber intake (NDFI) had no significant difference in relation to feeding systems. According to NRC (2001), developing calves aged between 3 and 6 months require in minimum 23\% dietary NDF in order to achieve balance in the rumen microbial community. In the present study, dietary NDF was superior to both treatments, with values of 28.8 and $40.1 \%$ in feedlot and pasture diets, respectively. According to NRC (2001), the values from 1 to $1.2 \%$ of the animal live weight for NDF intake are ideal during the growing phase. Nonetheless, when exceeded, it would impair feed intake by filling the rumen-reticulum. The intake was 1.25 and $1.15 \%$ for feedlot and pasture, respectively. Berends et al. (2012), observed restrictions on intake due to the filling of rumenreticulum by excess fiber.

In relation to the NDF, Roman et al. (2011) describe that NDF digestibility is an important parameter in forage quality, since great part of forage used for feeding ruminants have a high variability in ruminal degradation. Consequently, it causes a great impact on animal development regardless breed. Considering that the digestibility of the silage provided was of good quality and it was very similar to the digestibility of the pastures, there was a combined effect with the concentrate. This allowed higher DM intake and higher weight gain, with no limitation due to fiber intake.

Animals finished in feedlot had higher $(\mathrm{P}<0.05)$ ADF intake when compared with animals finished on pasture as a result of lower ADF levels in ryegrass and millet pastures in relation to corn silage (Table II).

Daily intake of nutrients is directly correlated to the muscular development. The effects of growth are observed when there is synchrony in the supply of nutrients from the diet, demonstrating the normal development of animals (Van Den Borne et al. 2007). Therefore, the results found in this study show that the supply of nutrients has met the requirements for growth in young animals.

Differences in average daily weight gain (ADG) can be observed (Table VI), since feedlot animals were fed higher level of concentrate and they had higher DM intake, directly influencing weight gain. The ADG affected the feedlot period length, in which animals in feedlot and on pasture spent 149 and 215 days to reach $200 \mathrm{~kg}(\mathrm{P}<0.05)$, respectively. The average daily weight gain of animals on pasture was lower to those found by

TABLE IV

Initial Weight (IW), Final weight (FW), Termination days, average daily gain (ADG) and food conversion (FC) of Holstein calves terminated in feedlot or pasture.

\begin{tabular}{|c|c|c|c|c|}
\hline \multirow{2}{*}{ Variable } & \multicolumn{2}{|c|}{ Feeding System } & \multirow[b]{2}{*}{$\mathbf{P}>\mathbf{F}$} & \multirow[b]{2}{*}{ CV \% } \\
\hline & Feedlot & Pasture & & \\
\hline IW (kg) & 62.33 & 57.94 & - & - \\
\hline FW (kg) & $200.31 \pm 8.63$ & $206.14 \pm 8.63$ & 0.6427 & 20.30 \\
\hline Termination days & $149 \pm 8.4$ & $215 \pm 7.8$ & $<0.0001$ & 45.26 \\
\hline ADG (kg) & $0.949 \pm 0.04$ & $0.694 \pm 0.04$ & 0.0141 & 21.28 \\
\hline $\mathrm{FC}\left(\mathrm{kg} 1 \mathrm{~kg}^{-1} \mathrm{ADG}\right)$ & $6.05 \pm 0.14$ & $6.32 \pm 0.16$ & 0.1543 & 11.02 \\
\hline
\end{tabular}

(-) No meaningful data for statistical analysis. 
Roma Junior et al. (2008) using Zebu x Holstein and Holstein in feedlot. The authors observed an ADG of 1.45 and $1.16 \mathrm{~kg} \mathrm{day}^{-1}$, respectively; however, the average weight gain expected for young dairy animals (after weaning) is $0.861 \mathrm{~kg} \mathrm{day}^{-1}$, which is similar to those measured in this study. In this sense, Holstein calves have potential for meat production in young age. We must emphasize that the animals on pasture had lower weight gains even with the supply of high nutritive pasture and concentrate; however, the energy expenditure for grazing and high ambient temperatures $\left(36^{\circ} \mathrm{C}\right.$ in February) interfered on the efficiency of weight gain compared to animals confined in covered stalls.

Feed conversion (FC) did not differ between diets $(\mathrm{P}>0.05)$. Despite the fact that the animals kept in feedlot gained more weight, these animals showed a higher dry matter intake as discussed previously; therefore, the efficiency gain was the same for animals finished in feedlot and on pasture.

The feed conversion is correlated to the protein content of the diet because the use of highly concentrated protein, especially for young animals, results in better conversion (Paulino et al. 2013). Confirming the use of feedlot, Vaz et al. (2013), when assessing beef cattle under feedlot from 7 to 14 months, found conversions varying from 4.78 to $5.21 \mathrm{~kg} \mathrm{day}^{-1}$, which were better than the values observed in this study in Holstein calves.

The results provided in the current study show that Holstein calves have a potential for the production of meat, expressing the best performance when finished in feedlot due to higher nutrient intake. The nutrients provided met the nutritional requirements of animals raised in feedlot and pasture; however, the shorter finishing period occurred in feedlot due to the higher average daily gain.

\section{ACKNOWLEDGMENTS}

We thank the Fundação Araucária do Paraná and the Conselho Nacional de Tecnologia e Pesquisa $(\mathrm{CNPq})$ for the financial support to carry out this research.

\section{REFERENCES}

AOAC - ASSOCIATION OF OFFICIAL ANALYTICAL CHEMISTS. 2012. Official methods of analysis. $19^{\text {th }}$ ed., Washington, D.C., 1094 p.

AHARONI Y, BROSH A, ORLOV A, SHARGAL E AND GUTMAN M. 2004. Measurement of energy balance of grazing beef cows on Mediterranean pasture, the effects of stocking rate and season 1. Digesta kinetics, faecal output and digestible dry matter intake. Livest Prod Sci 90: 89100.

BERENDS H, VAN DEN BORNE JJ, ALFERINK SJ, VANREENEN CG, BOKKERS EA AND GERRITS WJ. 2012. Low-protein solid feed improves the utilization of milk replacer for protein gain in veal calves. J Dairy Sci 95: 220-228.

CARDOSO RC, VALADARES-FILHO SC, SILVA JFC, PAULINO MF, VALADARES RFD, CECON PR, COSTA MAL AND OLIVEIRA RV. 2000. Consumo e digestibilidades aparentes totais e parciais de rações contendo diferentes níveis de concentrado, em novilhos F1 Limousin x Nelore. Rev Bras Zootec 29: 1832-1843.

COSTA MG, CAMPOS JMS, VALADARES-FILHO SC, VALADARES RFD, MENDONÇA SS, SOUZA DP AND TEIXEIRA MP. 2005. Desempenho produtivo de vacas leiteiras alimentadas com diferentes proporções de canade-açúcar e concentrado ou silagem de milho na dieta. Rev Bras Zootec 34: 2437-2445.

FERNANDES HJ, PAULINO MF, MARTINS RGR, VALADARES-FILHO SC, TORRES RA, PAIVA LM AND MORAES GFBK. 2004. Ganho de peso, conversão alimentar, ingestão diária de nutrientes e digestibilidade de garrotes não-castrados de três grupos genéticos em recria e terminação. Rev Bras Zootec 33: 2403-2411.

FIEMS LO, BOEVER JL, VANACKER JM, CAMPENEERE S AND BRABANDER DL. 2012. Spelt as an ingredient in concentrates for rearing calves. Liv Sci 150: 349-356.

FIGUEIRAS JF, EDENIO D, PAULINO MF, VALENTE TNP, VALADARES-FILHO SC AND LAZZARINI I. 2010. Intake and digestibility in cattle under grazing supplemented with nitrogenous compounds during dry season. Rev Bras Zootec 39: 1303-1312.

KUNKLE WE AND BATES DB. 1998. Evaluating feed purchasing options: energy, protein, and mineral supplements. In: Florida Beef Cattle Short Course 
Proceedings... Gainesville: University of Florida, 1998, p. 119-126.

MISSIO RL, BRONDANI IL, FREITAS LS, SACHET RH, SILVA JHS AND RESTLE J. 2009. Desempenho e avaliação econômica da terminação de tourinhos em confinamento alimentados com diferentes níveis de concentrado na dieta. Rev Bras Zootec 38: 1309-1316.

MOUSQUER CJ, FERNANDES GA, FERNANDES FFD, FERREIRA VB, BARBOSA LAB, FREIRIA LB, SILVA MR AND CASTRO WJR. 2013. Produção de carne de vitelo: sistemas produtivos e aspectos zootécnicos. PUBVET 7: 23.

NRC - NATIONAL RESEARCH COUNCIL. 2001. Nutrient requirements of dairy cattle. National Academic Press, $7^{\text {th }}$ ed., Washington, D.C., 381 p.

PAULINO PVR, OLIVEIRA TS, GIONBELI PM AND GALLO SB. 2013. Dietas Sem Forragem para terminação de Animais Ruminantes. Rev Cient Prod Ani 15: 161-172.

ROMA JUNIOR LC, SAVASTANO JÚNIOR H, MARTELLO LS, LEME PR AND PINHEIRO MG. 2008. Produção de vitelos a partir de bezerros leiteiros mestiços e da raça Holandesa. Rev Bras Zootec 37: 1088-1093.

ROMAN J, JOBIM CC, RESENDE FD, SIQUEIRA GR, FARIA MH AND OLIVEIRA NETO RA. 2011.
Performance of finishing beef cattle fed different diets containing whole-crop maize silage or sugarcane silage. Rev Bras Zootec 40: 682-689.

SAS INSTITUTE. SAS/STAT. 2002. User's guide: statistics. Versão 9.0. $5^{\text {th }}$ ed., Cary: SAS USA Institute.

TILLEY JMA AND TERRY RAA. 1963. Two-stage technique for the in vitro digestion of forage crops. J Brit Grass Soc 18: 104-111.

VAN DEN BORNE JJ, HOCQUETTE JF, VERTEGEN MW AND GERRITS WJ. 2007. Whole body and muscle energy metabolism in pre ruminant calves: effects of nutrient synchrony and physical activity. Brit J Nutri 97: 667-675.

VAN SOEST PJ, ROBERTSON JB AND LEWIS BA. 1991. Methods for dietary fiber, neutral detergent fiber, and nonstarch polyssacharides in relation to animal nutrition. J Dairy Sci 74: 3583-3590.

VAZ FN, RESTLE J, FLORES JLC, VAZ RZ AND PACHECO PS. 2013. Desempenho em confinamento de machos bovinos super jovens de diferentes grupos genéticos. Ciênc Agron 44: 167-173.

WILLIAMS CH, DAVID DJ AND ILSMAA O. 1962. The determination of chromic oxide in feaces samples by atomic absorption spectrophotometry. J Agric Sci 59: 381-385. 